\title{
STRUKTUR KOMUNITAS TERUMBU KARANG DI PESISIR KECAMATAN BULELENG SINGARAJA
}

\author{
I Nyoman Dodik Prasetia1', I Gede Yudi Wisnawa² \\ 1Jurusan Budidaya Kelautan, Universitas Pendidikan Ganesha \\ Singaraja, Indonesia \\ 2Jurusan Survey dan Pemetaan, Universitas Pendidikan Ganesha \\ Singaraja, Indonesia \\ e-mail :dodik_prasetia@yahoo.com,yudiwisnawa@gmail.com
}

\begin{abstract}
Abstrak
Terumbu karang merupakan salah satu sumber daya alam kelautan yang dimiliki Kabupaten Buleleng. Penelitian Struktur Komunitas Terumbu Karang bertujuan untuk mengetahui potensi dan kondisi ekosistem terumbu serta struktur komunitas ekosistem terumbu karang dan mengetahui potensi dan kondisi ekosistem terumbu karang. Metode yang akan dipergunakan adalah manta tow survey, line intercept transect, survey sensus dan analisa sifat fisik kimia perairan. Penelitian menunjukkan penutupan karang hidup di pesisir Kecamatan Buleleng dari 3 stasiun penelitian dengan kategori buruk sampai baik, pada kedalaman 3 meter berkisar antara 16,78 \% sampai 51,98\% dan kedalaman 10 meter dengan penutupan $19,06 \%$ sampai $22,98 \%$. Ikan karang yang berasosiasi dengan karang ditemukan 34 jenis dengan jumlah 665 individu pada stasiun 1, stasiun 2 dengan jumlah 359 individu, serta di stasiun 3 ditemukan 186 individu. Kondisi fisik dan kimia air laut yang masih dalam ambang batas kategori toleransi pertumbuhan dan perkembangan terumbu karang.
\end{abstract}

Kata kunci: terumbu karang, line intercept transect, struktur komunitas, tutupan karang hidup

\begin{abstract}
The research aims to determine the potency and conditions of the coral reef ecosystems and structure community coral and also to determine the potency and the condition of coral reef ecosystems in the Buleleng coastal area. Methods used are the manta tow surveys, intercept transect line, visual census and physical chemical waters analysis. Research showed live coral covering in the Buleleng coastal district in 3 research stations with poor to good category, at a depth of 3 meters ranged from $16.78 \%$ to $51.98 \%$ and a depth of 10 meters with $19.06 \%$ to $22.98 \%$. Fish associated with coral reefs found 34 species with a number of 665 fishes on station 1, 359 in station 2, and 186 in station 3. Physical and chemical conditions in the sea water are still a threshold of tolerance category growth and development of coral reefs.
\end{abstract}

Keywords: coral reef, structure community, line intercept transect, live coral covering 


\section{PENDAHULUAN}

Terumbu karang merupakan salah satu sumberdaya alam kelautan yang dimiliki Kabupaten Buleleng, dimana sumberdaya alam ini mempunyai peran penting baik ditinjau dari aspek konservasi, produksi maupun pariwisata dan rekreasi. Ditinjau dari aspek konservasi, terumbu karang mempunyai fungsi dalam hal pemeliharaan proses-proses ekologis dan sistem penyangga kehidupan di wilayah pesisir dan laut, habitat berbagai jenis biota sehingga berfungsi sebagai pengawetan keanekaragaman hayati dan plasma nutfah, melindungi pantai dari bahaya erosi dan abrasi, serta sebagai penghasil pasir putih. Ditinjau dari aspek produksi, keberadaan ekosistem terumbu karang telah memberi manfaat yang besar bagi pemenuhan kebutuhan pangan dan menopang mata pencaharian masyarakat pesisir melalui kegiatan perikanan.

Ekosistem terumbu karang merupakan habitat berbagai biota laut bernilai ekonomis penting. Peranan terumbu karang dalam menunjang kegiatan perikanan setidak-tidaknya dapat dilihat dari tiga aspek yaitu penangkapan ikan secara langsung di dalam ekosistem terumbu karang, penangkapan ikan di sekitar terumbu karang dan penangkapan ikan di laut lepas yang produktivitasnya didukung oleh keberadaan ekosistem terumbu karang.

Fungsi-fungsi ekosistem terumbu karang tersebut hanya dapat diperoleh secara optimal jika kondisi terumbu karang berada dalam status yang sehat. Di sisi lain, seiring dengan pembangunan dan laju pemanfaatan sumberdaya di wilayah pesisir yang semakin intensif, beban wilayah pesisir semakin meningkat termasuk terhadap ekosistem terumbu karang yang ada di dalamnya. Pemanfaatan sumberdaya ekosistem terumbu karang secara berkelanjutan bagi pembangunan dan kesejahteraan masyarakat dewasa ini dihadapkan pada permasalahan yaitu semakin meluasnya kerusakan terumbu karang. Ancaman terhadap kerusakan terumbu karang di Bali pada umumnya terutama disebabkan oleh kegiatan manusia, seperti pembuangan limbah yang menyebabkan meningkatnya pencemaran, praktek-praktek perikanan yang merusak (destructive fishing), wisata bahari yang tidak terkontrol, sedimentasi, dan lain sebagainya.

Kabupaten Buleleng dengan panjang garis pantai lebih kurang $144 \mathrm{~km}$ meliputi 7 (tujuh) Kecamatan menunjukkan bahwa beberapa titik lokasi sepanjang pantai tersebut merupakan sebaran terumbu karang. Penelitian Prasetia Tahun 2011, di Kawasan Lovina secara umum dikategorikan sebagai terumbu karang tipe terumbu penghalang, tersebar di beberapa titik-titik sepanjang perairan Lovina. Kondisi penutupan karang hidup di Kawasam Lovina yang meliputi Desa Tukad Mungga, Anturan, Bakti Seraga, Banyuasri, Anturan dan Kalibukbuk berkisar antara 18 sampai $44 \%$ penutupan karang hidup dengan kategori buruk sampai sedang. Struktur komunitas terumbu karang Kawasan Lovina memiliki formasi Acropora, Non Acropora, Soft Coral, dan Sponges. Kelompok Acropora umumnya berbentuk branching, digitate, submassive, kelompok Non Acropora dengan lifeform : branching, massive, encrusting, submassive, foliose dan mushroom.

Kawasan Pesisir Kecamatan Buleleng memiliki potensi terumbu karang yang relatif tinggi, namun tingginya manfaat terumbu karang ini tidak disertai dengan 
usaha pemanfaatan yang lestari, sehingga terjadi kecenderungan semakin menurunnya daya dukung ekosistem ini. Potensi terumbu karang di Pesisir Kecamatan Buleleng tidak disertai dengan data ilmiah tentang kondisi dan struktur komunitas serta interaksi organisme pemanfaat ekosistem terumbu karang. Permasalahan di atas mendorong pentingnya penelitian tentang struktur komunitas ekosistem terumbu karang, sehingga terpantau kondisi dan potensi terumbu karang di Kawasan Pesisir Kecamatan Buleleng.

\section{METODE}

Penelitian dilaksanakan di Pesisir Kecamatan Buleleng, Kabupaten Buleleng, Provinsi Bali pada bulan Maret sampai Oktober 2013.

Penelitian dilaksanakan dengan diawali dengan pengamatan kondisi umum ekosistem terumbu karang di kawasan ini dengan menggunakan metode Manta Tow Survey. Menurut English, et all tahun 1994, metode ini merupakan metode observasi/ pemantauan terhadap suatu komunitas terumbu karang dalam skala yang luas dalam waktu yang singkat.

Data dari metode Manta Tow Survey dianalisa dan digunakan sebagai dasar pembuatan peta kondisi terumbu karang secara umum. Peta ini akan dijadikan dasar penentuan stasiun pengamatan terumbu karang dengan metode recruitmen karang dan Line Intercept Transect.

Metode Line Intercept Transect dilaksanakan untuk mengkaji komunitas bentik berdasarkan karakteristik life form terutama morfologi dari komunitas terumbu karang, sehingga dapat diketahui keanekaragaman jenis karang di daerah tersebut. Pengamatan dengan Line Intercept Transect dilakukan dengan SCUBA diving pada kedalaman $3 \mathrm{~m}$ dan $10 \mathrm{~m}$ (English et all, 1994). Pengukuran dilakukan pada dua kedalaman ini dengan asumsi dua kedalaman tersebut dianggap mewakili kondisi karang karena biasanya karang tumbuh dengan baik dan keragaman jenis karang yang tinggi juga diperoleh pada kedalaman tersebut.

Pengamatan ikan karang dilakukan sepanjang transek garis dengan mencatat jenis dan kelimpahan ikan dalam jangkauan 2,5 meter di kiri dan kanan transek. Pencatatan ikan karang hingga spesies dilakukan dalam luasan $5 \times 50$ meter. Parameter yang diamati meliputi :

1. Nilai keanekaragaman, keseragaman, dan dominansi jenis ikan karang;

2. Pengamatan terhadap ikan indikator di ekosistem terumbu karang.

Penelitian terhadap kondisi fisik yang diukur dan diamati langsung di lapangan pada masing-masing stasiun penelitian adalah suhu, kecepatan arus, kekeruhan, dan sampah serta tumpahan minyak.

Analisa data dengan menggunakan metode Line Intercept Transect dilakukan dengan memperhatikan prosentase penutupan suatu kategori pada transek garis sepanjang 50 meter. Dengan pembagian kategori penutupan karang sesuai dengan pendekatan Gomez dan Yap (1988) adalah :

$\begin{array}{ll}75-100 \% & \text { Sangat baik } \\ 50-75 \% & \text { Baik } \\ 25-50 \% & \text { Sedang } \\ 0-25 \% & \text { Buruk }\end{array}$

Indeks Keanekaragaman yang dipergunakan adalah indeks Shannon- 
Wiener yang diterapkan pada komunitas acak dengan ukuran yang besar, dimana jumlah total spesies diketahui (Krebs, 1972). Keseimbangan komunitas ikan karang digunakan Indeks Keseragaman, yaitu ukuran kesamaan jumlah individu antar spesies dalam suatu komunitas.

Tingkat kerusakan ini terkait dengan penutupan karang mati dan pecahan karang yang terjadi. Untuk menduga tingkat kesehatan atau kondisi ekosistem terumbu karang digunakan indeks mortalitas dengan perhitungan (Gomez, 1994).

\section{HASIL DAN PEMBAHASAN}

Terumbu karang Pesisir Kecamatan Buleleng secara umum dikategorikan sebagai terumbu karang tipe terumbu penghalang (barrier reef) tersebar di beberapa titik-titik sepanjang perairan Kecamatan Buleleng, meskipun dalam kurun waktu yang lalu dijumpai tipe terumbu tepi. Formasi terumbu karang tepi sejatinya memiliki keuntungan dalam proteksi daratan dari ancaman abrasi dari energi gelombang tetapi mudah terdegradasi oleh aktivitas manusia di daratan Hal ini terjadi di Kawasan Pesisir Kecamatan Buleleng karena tingginya tekanan yang didapatkan dari daratan, sehingga ekosistem terumbu karang tipe tepi menjadi tertekan.

Tingginya tingkat aktivitas dan interaksi manusia dengan lingkungan, berpotensi menurunkan daya dukung lingkungan khususnya ekosistem terumbu karang. Seperti yang diungkapkan oleh World Research Institute (2000) dan Ranjbar (2010), penyebab utama kerusakan terumbu karang adalah oleh aktivitas manusia (anthropogenic impact).

Pengamatan dengan manta tow survey menunjukkan keberadaan terumbu karang kurang lebih 50 meter dari garis pantai, sepanjang pantai Desa Penarukan, Banyuning, Kampung Baru, Kampung Bugis, Kampung Anyar, dan Banyuasri. Kategori penutupan karang hidup di Kawasan Pesisir Kecamatan Buleleng menggunakan manta tow survey menunjukkan kategori antara buruk sampai baik. Kondisi ini terjadi karena beberapa sungai bermuara di kawasan ini. Sistem terumbu karang merupakan ekosistem yang rentan terhadap perubahan kondisi lingkungan. Beberapa syarat lingkungan yang harus dipenuhi untuk pertumbuhan dan perkembangan optimal dari terumbu karang di Kecamatan Tejakula seperti suhu. Secara global, sebarang terumbu karang dunia dibatasi oleh permukaan laut yang isoterm pada suhu $20{ }^{\circ} \mathrm{C}$, dan tidak ada terumbu karang yang berkembang di bawah suhu $18{ }^{\circ} \mathrm{C}$. Terumbu karang tumbuh dan berkembang optimal pada perairan bersuhu rata-rata tahunan 23 - 25 ${ }^{\circ} \mathrm{C}$, dan dapat menoleransi suhu sampai dengan $36-40{ }^{\circ} \mathrm{C}$.

Hal kedua yang harus terpenuhi adalah faktor salinitas, terumbu karang hanya dapat hidup di perairan laut dengan salinitas normal 32 - 35 \%. Umumnya terumbu karang tidak berkembang di perairan laut yang mendapat limpasan air tawar teratur dari sungai besar, karena hal itu berarti penurunan salinitas.

Kedua faktor tersebut berperan penting untuk kelangsungan proses fotosintesis oleh zooxantellae yang terdapat di jaringan karang. Terumbu yang dibangun karang hermatipik dapat hidup di perairan dengan kedalaman maksimal 5070 meter, dan umumnya berkembang di kedalaman 25 meter atau kurang. Titik kompensasi untuk karang hermatipik berkembang menjadi terumbu adalah pada 
kedalaman dengan intensitas cahaya 15$20 \%$ dari intensitas di permukaan.

Faktor ini berhubungan dengan penetrasi cahaya. Kecerahan perairan tinggi berarti penetrasi cahaya yang tinggi dan ideal untuk memicu produktivitas perairan yang tinggi pula. Paparan udara terbuka merupakan faktor pembatas karena dapat mematikan jaringan hidup dan alga yang bersimbiosis di dalamnya.

Gelombang merupakan faktor pembatas karena gelombang yang terlalu besar dapat merusak struktur terumbu karang, contohnya gelombang tsunami. Namun demikian, umumnya terumbu karang lebih berkembang di daerah yang memiliki gelombang besar. Aksi gelombang juga dapat memberikan pasokan air segar, oksigen, plankton, dan membantu menghalangi terjadinya pengendapan pada koloni atau polip karang.

Faktor arus dapat berdampak baik atau buruk. Bersifat positif apabila membawa nutrien dan bahan-bahan organik yang diperlukan oleh karang dan zooxanthellae, sedangkan bersifat negatif apabila menyebabkan sedimentasi di perairan terumbu karang dan menutupi permukaan karang sehingga berakibat pada kematian karang.

Pesisir Kecamatan Buleleng memiliki penilaian sedang sebagai kawasan yang berpotensi dalam pengembangan kegiatan rehabilitasi ekosistem terumbu karang di Kabupaten Buleleng. Kondisi ekosistem terumbu karang saat ini sangat memungkinkan ditingkatkan penutupan karang hidupnya dengan kerjasama semua pihak terkait di kawasan ini.

Daerah aliran sungai di Kawasan Pesisir Kecamatan Buleleng yang pada waktu penghujan membawa sedimen ke perairan merupakan faktor alam yang turut mengendalikan pertumbuhan karang. Sedimentasi secara langsung dan tidak langsung mempengaruhi pertumbuhan karang karena banyaknya energi yang dikeluarkan untuk menghalau sedimen ini agar tidak ke permukaan polip (Pastorok dan Bilyard, 1985 dalam Supriharyono, 2000). Meningkatnya sedimen akan mematikan karang dan tambahan unsur hara dapat menyebabkan karang ditumbuhi alga yang menjadi pesaing karang dalam hidup (Anonim, 2002). Hal ini disebabkan sedimen yang berlebihan dapat mematikan karang, karena oksigen terlarut dalam air tidak dapat berdifusi masuk ke dalam polip karang (Dahuri, et all. 1996)

Pengamatan dengan line intercept transect dilakukan pada 3 titik stasiun penelitian yang diperoleh dari pengundian hasil pementaan dengan menggunakan manta tow survey. Hal ini dilakukan dengan mempertimbangkan keterwakilan setiap wilayah pengamatan, sehingga diharapkan hasil yang didapat mewakili kondisi ekosistem terumbu karang di kawasan penelitian.

Secara umum Penelitian menunjukkan penutupan karang hidup di pesisir Kecamatan Buleleng dari 3 stasiun penelitian dengan kategori buruk sampai baik, pada kedalaman 3 meter berkisar antara $16,78 \%$ sampai $51,98 \%$ dan kedalaman 10 meter dengan penutupan $19,06 \%$ sampai 22,98\%. Hal ini menunjukkan hasil yang tidak jauh berbeda dengan pengamatan menggunakan manta tow survey.

Struktur komunitas terumbu karang di Kawasan Pesisir Kecamatan Buleleng memiliki formasi Acropora, Non Acropora, dan soft coral. Kelompok Acropora umumnya berbentuk branching, tabulate 
dan submassive, kelompok Non Acropora dengan lifeform :branching, massive, encrusting, submassive, foliose dan mushroom.

Pengamatan pada Stasiun 1 yang merupakan kawasan Desa Kampung Baru menunjukkan prosentase penutupan karang hidup kelompok non Acropora di kedalaman 10 meter 19,36 \% sedangkan di 3 meter $15,09 \%$. Hal ini mengidikasikan tingginya tekanan komunitas karang pada kedalaman
3 meter yang berinteraksi langsung dengan daratan.

Kelompok Acropora branching yaitu karang berbentuk bercabang seperti ranting pohon, seperti: Acropora palmata, A. Formosa. Kelompok Acrophora yang lain adalah Acropora digitate yaitu karang berbentuk percabangan rapat dengan cabang seperti jari-jari tangan, seperti jenis: $A$. humilis, $A$. digitifera dan $A$. gemmifera, meskipun dengan jumlah yang relatif tidak banyak.

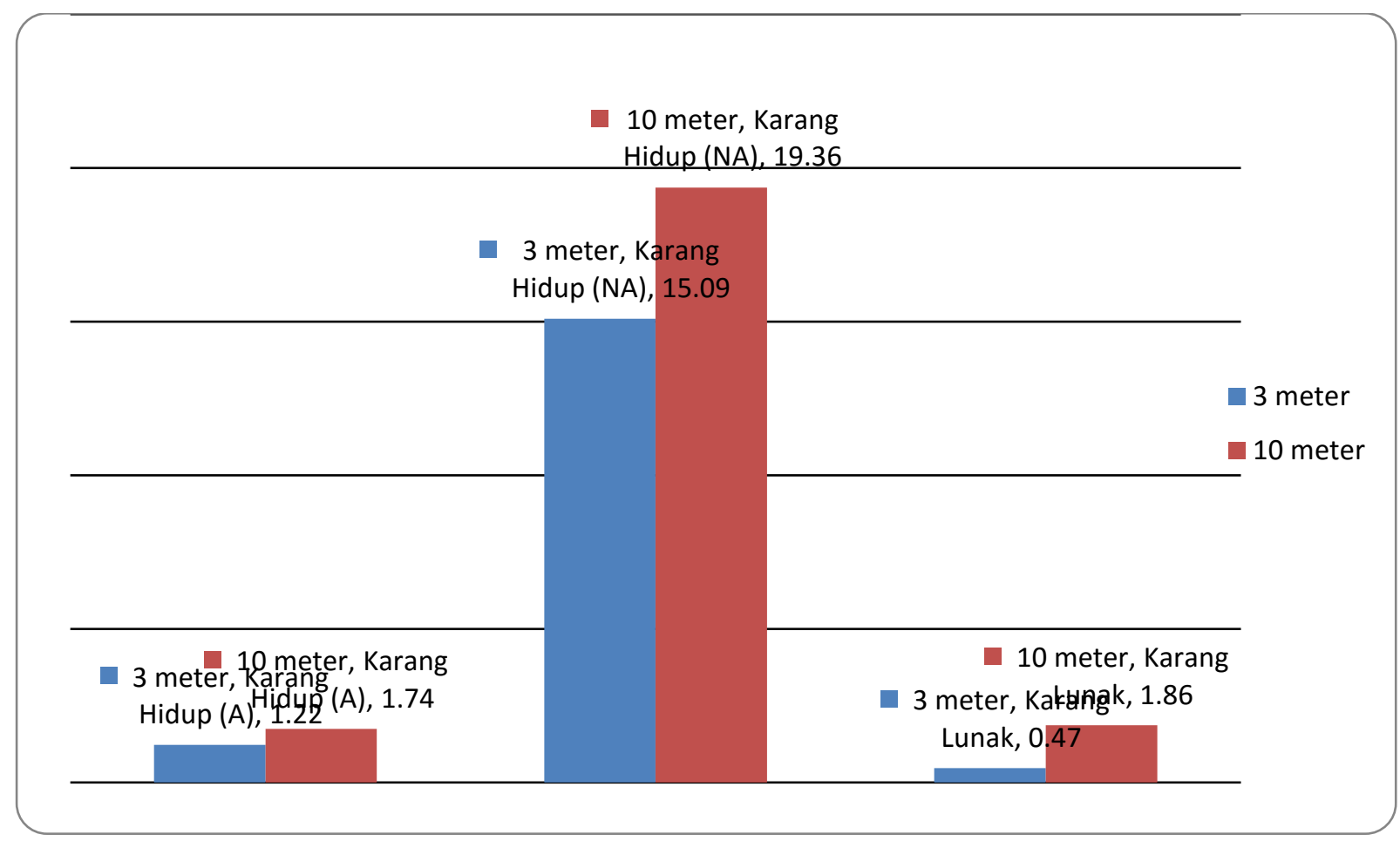

Gambar 1. Kondisi Karang di Stasiun 1

Hasil pengamatan tutupan karang di Stasiun 2 yang merupakan kawasan Pantai Desa Kampung Bugis, menunjukkan Tingginya tekanan terhadap ekosistem terumbu karang di kawasan ini mengakibatkan tidak optimalnya pertumbuhan dan perkembangan individu karang di kawasan ini. Tekanan ini berasal dari aktivitas manusia sebagai pemanfaat pesisir dan alam itu sendiri. 
Aktivitas manusia terdiri dari pembangunan yang tidak berwawasan kelestarian lingkungan, kegiatan perikanan yang merusak, khususnya dalam hal membuang sampah. Hal ini terlihat dari banyaknya sampah yang menutupi ekosistem terumbu karang.

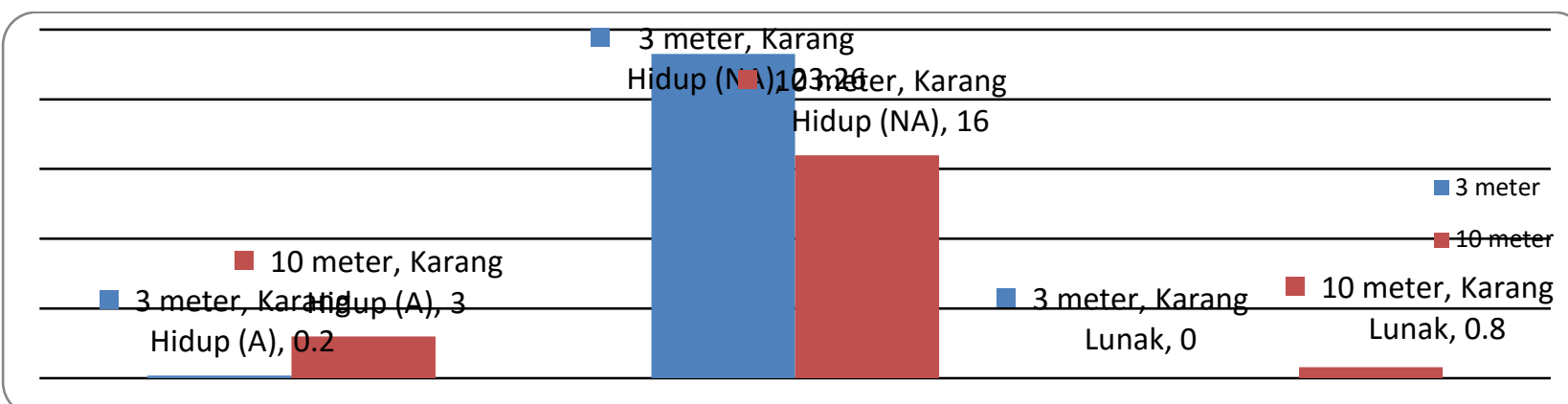

Gambar 2. Kondisi Karang di Stasiun 2

Struktur komunitas karang di Stasiun 2 terdiri dari karang kelompok acropora dan non acropora, sedangkan karang lunak hanya ditemukan pada kedalaman 10 meter dengan jumlah penutupan hanya $0,8 \%$.

Stasiun 3 yang berada di kawasan Desa Kampung Anyar didominasi oleh kelompok karang non acropora yang kebanyakan memiliki bentuk massive. Kondisi perairan yang dipenuhi oleh sampah pada saat tertentu menyebabkan karang tidak dapat tumbuh dan berkembang dengan baik.

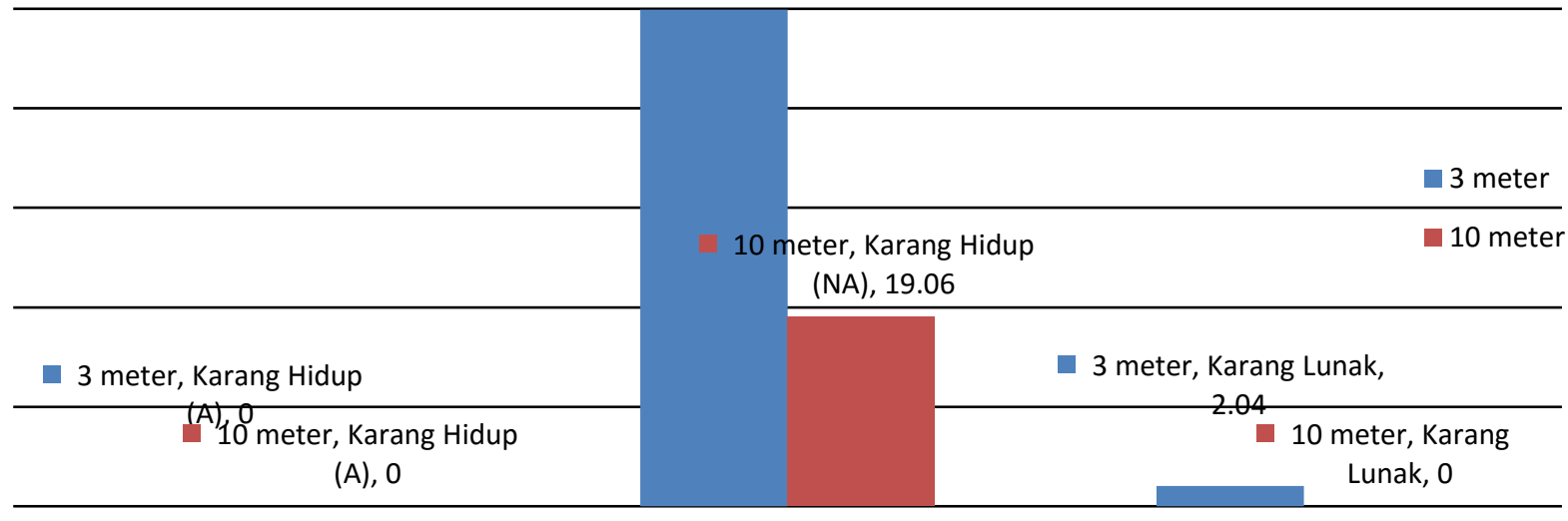

Gambar 3. Kondisi Karang di Stasiun 
Tingkat kerusakan terumbu karang sangat berkaitan dengan penutupan karang mati dan pecahan atau patahan karang. Indikasi yang dipakai bahwa suatu kawasan mengalami kerusakan pada terumbu karangnya adalah: penutupan pecahan atau patahan karang (rubble) dan keberadaan alga. Rubble merupakan bentuk dari patahan-patahan karang yang tidak beraturan yang dapat diakibatkan oleh bencana alam, penggunaan bahan peledak untuk mencari ikan, penambangan karang untuk bahan bangunan, pembuangan jangkar, dan aktivitas manusia lainnya yang merusak. Alga merupakan salah satu kompetitor hidup bagi terumbu karang, alga akan sangat sulit untuk hidup dan tumbuh di atas terumbu karang yang baik.

Penutupan karang mati dan karang mati yang ditumbuhi alga sebanyak $62,1 \%$, dengan rincian Stasiun 1 karang mati antara $47,69 \%$ sampai $50,54 \%$, Stasiun 2 $62,1 \%$, dan Stasiun 3 dengan $44,16 \%$ sampai $51,14 \%$, menunjukkan tingginya tingkat tekanan yang dihadapi ekosistem terumbu karang di Pesisir Kecamatan Buleleng. Tekanan lebih dominan dikarenakan adanya aliran sungai di kawasan, yang pada saat hujan membawa serta sedimen ke daerah terumbu karang. Faktor kedua yang mempengaruhi adalah aktivitas manusia berupa penangkapan ikan yang merusak pada masa lalu yang mengakibatkan karang harus mengalami proses pemulihan.

Indikasi yang dipakai bahwa suatu kawasan mengalami kerusakan pada terumbu karangnya adalah : penutupan pecahan / patahan karang (rubble) dan keberadaan alga. Rubble merupakan bentuk dari patahan-patahan karang yang tidak beraturan yang dapat diakibatkan oleh bencana alam, penggunaan bahan peledak untuk mencari ikan, penambangan karang untuk bahan bangunan, pembuangan jangkar, dan aktivitas manusia lainnya yang merusak. Alga merupakan salah satu kompetitor hidup bagi terumbu karang, alga akan sangat sulit untuk hidup dan tumbuh di atas terumbu karang yang baik.

Secara fisik, terumbu karang berperan dalam perlindungan pantai dari pengikisan akibat arus, angin dan hempasan ombak yang kuat (Reksodihardjo dan Lilley, 1996). Secara sosial ekonomi terumbu karang berfungsi sebagai daerah perikanan, pariwisata, pertambangan baru, dan pemanfaatan lainnya (Dahuri, 1993). Ekosistem terumbu karang juga merupakan sumber plasma nutfah dan biodversitas, karena menyediakan habitat bagi tumbuhan seperti : melekatnya algae, hewan untuk mencari makan (feeding ground), sebagai tempat memijah (spawning ground), serta tempat pengasuhan (nursery ground) (Supriharyono 2000).

Fungsi ekologis merupakan fungsi ekosistem terumbu karang secara fisik dan biologis. Terumbu karang berfungsi sebagai filter air untuk menjaga kualitas air pantai sebagai pelemah tenaga gelombang, perlindungan alamiah terhadap daratan pantai dan pulau-pulau, meminimalkan erosi dan gangguan-gangguan di belakang terumbu, serta sebagai penghasil pasir putih bagi pantai dan pulau-pulau (Baker dan Kaeoniam, 1986)

Organisme-organisme yang berinteraksi dengan karang pada ekosistem terumbu karang juga memiliki nilai ekonomis yang tinggi. Jenis-jenis ikan karang, seperti ikan Napoleon atau ikan wrasse (Cheilinus undulatus) yang memiliki nilai ekspor yang tinggi. Udang barong (spiny lobster), kima (Tridagna sp), dan 
teripang (Holothuroidea) banyak dimanfaatkan dan memiliki nilai ekonomi yang tinggi (Supriharyono, 2000). Oleh karena semua itu terumbu karang merupakan habitat yang unik dengan produktivitas yang sangat tinggi.

Terumbu karang bukan merupakan sistem yang statis dan sederhana, melainkan suatu ekosistem yang dinamis dan kompleks. Tingginya produktivitas primer di ekosistem terumbu karang, bisa mencapai $5000 \mathrm{~g} \mathrm{C} / \mathrm{m}^{2} /$ tahun, memicu produktivitas sekunder yang tinggi, yang berarti komunitas makhluk hidup yang ada di dalamnya sangat beraneka ragam dan tersedia dalam jumlah yang melimpah. Berbagai jenis makhluk hidup yang ada di ekosistem terumbu karang saling berinteraksi satu sama lain, baik secara langsung maupun tidak langsung, membentuk suatu sistem kehidupan. Sistem kehidupan di terumbu karang dapat bertambah atau berkurang dimensinya akibat interaksi kompleks antara berbagai kekuatan biologis dan fisik.

Secara umum interaksi yang terjadi di ekosistem terumbu karang terbagi atas interaksi yang sifatnya sederhana, hanya melibatkan dua jenis biota dan interaksi yang bersifat kompleks karena melibatkan biota dari berbagai spesies dan tingkatan trofik. Berbagai macam interaksi yang bersifat sederhana, yang dapat berupa persaingan, pemangsaan oleh predator, grazing, komensalisme dan mutualisme, beserta contohnya di ekosistem terumbu karang.

Terumbu karang sebagai rumah ikan-ikan karang memiliki peranan yang sangat penting bagi keberlangsungan hidup ikan karang. Semakin tinggi kualitas dan kuantitas ekosistem terumbu karang pada umumnya akan meningkatkan kehadiran ikan-ikan karang di ekosistem ini. Kehadiran ikan-ikan karang yang berasosiasi dengan terumbu karang akan meningkatkan daya dukung lingkungan pesisir di kawasan ini.

Komunitas ikan di ekosistem terumbu karang terdapat dalam jumlah yang besar dan terlihat mengisi seluruh daerah di terumbu, sehingga dapat dikatakan bahwa ikan merupakan penyokong berbagai macam hubungan yang ada dalam ekosistem terumbu.

Tingginya keanekaragaman jenis dan kelimpahan komunitas ikan di ekosistem terumbu disebabkan oleh tingginya variasi habitat terumbu atau beragamnya relung (niche) dari spesiesspesies ikan tersebut. Habitat di terumbu tidak hanya tersusun oleh komunitas karang saja, melainkan juga terdiri atas daerah berpasir, ceruk dan celah, daerah alga, serta zona-zona yang berbeda yang melintasi hamparan terumbu.

Ikan karang terbagi dalam 3 (tiga) kelompok yaitu: (1) ikan target yaitu ikanikan yang menjadi target penangkapan atau yang lebih dikenal oleh nelayan sebagai ikan konsumsi seperti Famili Serranide, Lutjanidae, Haemulidae, Lethrinidae; (2) ikan indikator yaitu ikan yang digunakan sebagai indikator bagi kondisi kesehatan terumbu karang di suatu perairan seperti Famili Chaetodontidae; dan (3) kelompok ikan lain (mayor famili) yang berperan dalam rantai makanan, karena peran lainnya belum diketahui seperti Famili Pomacentridae, Scaridae, Acanthuridae, Caesionidae, Siganidae, Muliidae, Apogonidae. Ikan jenis ini banyak dijadikan ikan hias air laut.

Komunitas ikan di ekosistem terumbu karang terdapat dalam jumlah 
yang besar dan terlihat mengisi seluruh daerah di terumbu, sehingga dapat dikatakan bahwa ikan merupakan penyokong berbagai macam hubungan yang ada dalam ekosistem terumbu.

Ikan yang berasosiasi dengan terumbu karang pada Stasiun 1 teramati 190 individu dari 20 jenis ikan pada kedalaman 3 meter dan pada kedalaman 10 meter ditemykan 475 individu dari 34 jenis ikan karang. Ikan yang sering ditemukan berasal dari kelompok Pomacentridae, seperti: Dascyllus vetuculatus, Pomacentrus lepidogenys, Pomacentrus sp, dan Chromis ternatensis.

Tingginya keanekaragaman jenis dan kelimpahan komunitas ikan di ekosistem terumbu disebabkan oleh tingginya variasi habitat terumbu atau beragamnya relung (niche) dari spesiesspesies ikan tersebut. Habitat di terumbu tidak hanya tersusun oleh komunitas karang saja, melainkan juga terdiri atas daerah berpasir, ceruk dan celah, daerah alga, serta zona-zona yang berbeda yang melintasi hamparan terumbu.

Stasiun 2 memiliki keanekaragaman ikan yang terdiri dari 26 jenis dengan 98 individu pada kedalaman 3 meter dan 261 individu dari 24 jenis pada kedalamanan 10 meter. Ikan yang dominan ditemukan berasal dari kelompok Apogonidae, seperti: Apogon compressus Cheilodipterus quinquelineatus, novemfasciatus, dan Apogon nematoptera.

Sphaeramia

Stasiun 3 ikan karang yang sering ditemukan berasal dari kelompok Pomacentridae yang terdiri dari jenis: Chromis tornatensis, Pomacentrus simsiang, Pomacentrus bankanensis, Chromis analis, Chromis margaritifer, dan Dascyllus trimaculatus Jenis ikan yang ditemukan pada Stasiun 3 di kedalaman 3 meter terdiri dari 26 jenis dengan 84 individu dan 102 individu pada kedalaman 10 meter.

Ekosistem terumbu karang di perairan laut Indonesia diperkirakan seluas $75.000 \mathrm{~km}^{2}$ (Direktur Bina Sumberdaya Hayati, 1997) dengan potensi lestari sumber daya ikan sebesar 25 - 45 ton $/ \mathrm{km}^{2} /$ tahun pada kondisi yang masih baik.

\section{Organisme-organisme}

yang berinteraksi dengan karang pada ekosistem terumbu karang juga memiliki nilai ekonomis yang tinggi. Jenis-jenis ikan karang, seperti ikan Napoleon atau ikan wrasse (Cheilinus undulatus) yang memiliki nilai ekspor yang tinggi. Udang barong (spiny lobster), kima (Tridagna sp), dan teripang (Holothuroidea) banyak dimanfaatkan dan memiliki nilai ekonomi yang tinggi (Supriharyono, 2000). Oleh karena semua itu terumbu karang merupakan habitat yang unik dengan produktivitas yang sangat tinggi.

Ikan sangat bermanfaat bagi manusia, yaitu sebagai sumber protein hewani. Protein hewani ini mengandung asam amino esensial yang penting bagi manusia. Demikian juga kandungan lemak ikan baik bagi kesehatan. Daging ikan mengandung lemak yang relatif rendah dibandingkan daging ayam dan sapi, serta kandungan kalsiumnya relatif tinggi. Di daerah-daerah pesisir, umumnya masyarakat memenuhi kebutuhan akan protein ini dari ikan hasil tangkapan di perairan sekitarnya.

Berbagai spesies ikan karang memiliki nilai ekonomi tinggi sebagai ikan hias. Keindahan warna, dan perilakunya menjadikan satwa ini digemari untuk 
dipelihara baik di aquarium maupun di kolam-kolam

Selain keanekaan relung hidup yang tinggi, ada faktor lain yang perlu dipertimbangkan yaitu tingkat spesialisasi yang tinggi dari tiap spesies. Banyak spesies ikan yang memiliki kebutuhan yang sama sehingga terdapat persaingan aktif, baik antara spesies yang berbeda maupun antara spesies yang sama. Persaingan ini kemudian menuju pada pembentukan relung ekologi yang lebih sempit lagi. Dengan demikian, di ekosistem terumbu karang seringkali terlihat bahwa pergerakan banyak spesies ikan sangat terlokalisasi, terbatas pada daerah-daerah tertentu, dan terdapat perbedaan yang nyata antara ikan-ikan yang aktif di malam dan siang hari

Menurut Burke, dkk. (2002), ekosistem terumbu karang yang ada di wilayah Asia Tenggara merupakan yang paling terancam di dunia. Besarnya ketergantungan manusia terhadap sumberdaya laut di seluruh Asia Tenggara telah menyebabkan eksploitasi yang berlebih sehingga banyak terumbu karang yang terdegradasi, khususnya di dekat pusat kepadatan penduduk. Sekitar $70 \%$ penduduk di kawasan ini hidup di sekitar 50 $\mathrm{km}$ pesisir.

Penyebab utama kerusakan terumbu karang yang merupakan rumah ikan karang adalah oleh aktivitas manusia (anthropogenic impact), misalnya melalui tangkap lebih (over-exploitation) terhadap hasil laut, penggunaan teknologi yang merusak, seperti potassium cyanide, bom ikan, muro ami dan lain-lain (Anonim, 2002).

Ditinjau dari segi ekonomi dan sosial, pengerusakan karang ini akan menurunkan pendapatan dan kesejahteraan masyarakat. Pengerusakan karang dapat mengakibatkan penurunan kualitas dan kuantitas ikan karang yang berasosiasi dengan ekosistem terumbu karang. Penurunan kualitas dan kuantitas ikan karang akan menyebabkan hilangnya sumber penghasilan nelayan yang mengandalkan hidupnya menangkap ikan karang, efek ini akan menjalar dan berdampak negatif bagi masyarakat

\section{PENUTUP}

Penelitian menunjukkan penutupan karang hidup di pesisir Kecamatan Buleleng dari 3 stasiun penelitian dengan kategori buruk sampai baik, pada kedalaman 3 meter berkisar antara $16,78 \%$ sampai $51,98 \%$ dan kedalaman 10 meter dengan penutupan $19,06 \%$ sampai $22,98 \%$.

Ikan karang yang berasosiasi dengan karang ditemukan 34 jenis dengan jumlah 665 individu pada stasiun 1, stasiun 2 dengan jumlah 359 individu dari 26 jenis, serta di stasiun 3 ditemukan 36 jenis dengan 186 individu. Kondisi fisik dan kimia air laut yang masih dalam ambang batas kategori toleransi pertumbuhan dan perkembangan terumbu karang.

Mengingat ekosistem terumbu karang Kecamatan Buleleng berada di tengah kota, diperlukan suatu kesepakatan dan komitmen bersama yang melibatkan masyarakat dan berdasarkan data-data ilmiah, tentang zona pemanfaatan sumberdaya pesisir di Kawasan Pesisir Kecamatan Buleleng yang lestari, bertanggungjawab, dan berkelanjutan. Sehingga ekosistem terumbu karang dapat menjadi ikon pelestarian alam di Kota Singaraja.

Penelitian tentang rekrutmen karang sangatlah diperlukan sebagai data dasar pengelolaan kawasan ekosistem terumbu 
karang, sehingga diperlukan penelitian lanjutan tentang pola rekrutmen karang dalam upaya recovery terumbu karang Kawasan Pesisir Kecamatan Buleleng.

\section{DAFTAR PUSTAKA}

Anonim. 2010. Buleleng dalam Angka. Badan Pusat Statistik Kabupaten Buleleng. Singaraja.

English, S.C. Wilkinson, and v. Baker, 1994. Survey Manual for Tropical Marine Resources, Australia Institute of Marine Science. Townsville.

Gomez, E.D and H.T. Yap. 1988. Monitoring Reef Conditions. In: Kenchington, R.A and B. E. T. Hudson (eds). Coral Reef Management Handbook. Unesco Regional Office for Science and Technology for South-East Asia. Jakarta.

Krebs, C. J. 1972. Ecology: The Experimental Analysis of Distribution and Abundance. Harper\&Row Publishers. New York.

Prasetia, I Nyoman Dodik. 2011. Rekrutmen Karang di Kawasan Wisata Lovina. Universitas Pendidikan Ganesha. Singaraja

Ranjbar. M. S. 2010. Coral mortality and serpulid infestations with red tide, in the Persian Gulf. Marine Biotecnology Journal. Springer Verlag. UK. 